\title{
Visual Arts Education for Young Children In Aotearoa New Zealand
}

\author{
Lisa Terreni
}

Lisa Terreni is a senior lecturer at Victoria University of Wellington's Faculty of Education, teaching in the early childhood education degree programs. She has been involved in early childhood education for many years, as a kindergarten teacher, a senior teacher, and a professional development adviser for the New Zealand Ministry of Education. She is also an artist. Lisa's research interests focus on exploring how visual art can be used to enhance young children's thinking, communication, and multiliteracy skills. She also has a keen interest in social and cultural diversity and how teachers can meet the needs of diverse communities. Her master's in education research focused on children's and teachers' use of an interactive whiteboard for visual art in a kindergarten setting. Her current PhD research is examining early childhood access to and use of art museums and galleries in New Zealand. Email: Lisa.Terreni@vuw.ac.nz

Visual art education plays a significant role in fostering young children's learning, thinking, and communicating. In New Zealand, approaches to early childhood visual art education have developed in response to international educational theories and trends, which, over the years, have often resulted in changes to pedagogy and practice in this domain. Currently, the national early childhood curriculum $\mathrm{Te}$ Whāriki includes references to visual art education in many of its learning strands. Whilst the curriculum has a strong sociocultural orientation to learning and teaching, approaches to early childhood visual art education are diverse. A brief historical overview of early childhood visual arts education in New Zealand is presented and, to conclude, three examples of current, innovative art projects are discussed.

Keywords: visual art education; Te Whāriki

A whakatauki (Māori proverb) that is sometimes used in relation to visual arts education in New Zealand declares: te toi whakairo, ka ihiihi, ka wehiwehi, ka aweawe te ao katoa - artistic excellence makes the world sit up in wonder (New Zealand Ministry of Education, 2014). The proverb speaks of the importance of the arts - how these contribute to a nation's identity both locally and internationally, how important these are to the spirit of a nation, and, consequently, how important it is to invest in the arts and arts education so a nation's citizens, particularly the children, can excel (Clark, Grey, \& Terreni, 2013).

This paper starts by discussing the New Zealand early childhood curriculum Te Whāriki (New Zealand Ministry of Education, 1996), describing some of the key philosophical and pedagogical beliefs that underpin the document, and discussing the connections these have to visual arts education for young children. A brief historical overview of early childhood visual arts education in New Zealand is presented to create a historical context for showing how paradigmatic changes have occurred in relation to visual art pedagogy and practice over the past hundred years. To conclude, I provide three examples of innovative art projects that illustrate some current teaching approaches and practices.

\section{The New Zealand Early Childhood Curriculum}

Te Whāriki he whāriki mātauranga mō ngā mokopuna o Aotearoa: Early Childhood Curriculum (New Zealand Ministry of Education, 1996) was developed in consultation with the early childhood community so that the principles of partnership inherent in the Treaty of Waitangi, New Zealand's founding document, were honoured (Ritchie, 2003; Te One, 2003). The aim of the document is to ensure that young children 0-5 years of age who attend early childhood services in New Zealand are given the opportunity to develop an understanding of the cultural heritages of the partners to the treaty (New Zealand Ministry of Education, 1996). By developing parallel, but not identical, curricula to meet the specific needs of Māori and all other young New Zealand children, Te Whāriki is unique in its bicultural approach to curriculum. 
Te Whāriki also addresses issues of cultural diversity within the curriculum. This is significant because of increasing cultural diversity in the population and the huge diversity of early childhood services within the sector itself. For example, the New Zealand early childhood education sector includes mainstream services such as kindergartens and childcare services, special character services such as Montessori and Steiner centres, and ethno-specific services such as Te Kohanga Reo, Māori immersion centres, and Pacific Island language nests. There are also early childhood centres with particular religious orientations. The metaphor provided by the title of the document (a whāriki is a woven mat) implies that this is a framework in which the strands and goals of curriculum are interwoven. The different types of early childhood services are also able to "weave their own mat" so that their programs are responsive to their children, families, context, and values (May, 2002).

Te Whāriki guides early childhood teaching practice through four key principles:

- Empowerment (Whakamana)

- Holistic development (Kotahitanga)

- Family and community (Whānau Tangata)

- Relationships (Ngā Hononga)

There are also five learning strands which suggest to teachers the types of learning experiences that need to be provided for infants, toddlers, and young children. Specific learning outcomes for children are identified in each of the learning strands. The strands include:

- Well-being (Mana Atua)

- Belonging (Mana Whenua)

- Contribution (Mana Tangata)

- Communication (Mana Reo)

- Exploration (Mana Aotūroa)

Te Whāriki draws from a range of theoretical positions: developmental, constructivist, ecological, and sociocultural. However, it important to note that since its inception, there has been an increasing shift away from developmental theory toward a more sociocultural orientation (Terreni, 2009). For instance, key statements of the document highlight "the critical role of socially and culturally mediated learning and of reciprocal and responsive relationships with people, places and things" and how children learn through "collaboration with adults and peers, through guided participation and observation of others, as well as through individual exploration and reflection” (New Zealand Ministry of Education, 1996, p. 9).

One of the most significant aspects of the New Zealand early childhood curriculum is that it challenges the traditional notion that curriculum is discipline based where subject matter is compartmentalized (Haggerty, 2003). Visual arts and the other knowledge domains (such as music, science, and mathematics) are not treated as separate subject-based disciplines. Rather, they are seen as integrated throughout an early childhood program. Curriculum, as described by Te Whāriki, is the "sum total of the experiences, activities, and events, whether direct or indirect, which occur within an environment designed to foster children's learning and development" (New Zealand Ministry of Education, 1996, p. 10). Consequently, the early childhood curriculum is substantially different from the curricula of the primary and secondary education sectors in New Zealand.

Most references to visual arts education appear in the communication strand, which focuses on the development of children's literacy (in the arts as well as written and oral language) and the fostering of creativity. There are specific learning outcomes that have implications for the provision of visual art experiences. For example, teachers are encouraged to provide children 
with an environment where they develop "an increasing familiarity with a selection of the art, craft, songs, music, and stories, which are valued by the cultures in the community," where "skills and confidence with the processes of art and craft, such as cutting, drawing, collage, painting, print-making, weaving, stitching, carving and constructing" are encouraged, and where children "experience the stories and symbols of their own and other cultures" (New Zealand Ministry of Education, 1996, p. 80; Terreni, 2008).

Specifying actual content of curriculum, which includes visual art, or providing a recipe for teacher practice is not the intention of the document. Rather, it provides a "framework for action guided by philosophic principles" (Te One, 2003, p. 42) and supports the "fundamentally interpretative nature of teaching" (Nuttall, 2003, p. 14). This idea applies equally to visual arts education as it does to other aspects of curriculum and, consequently, has resulted in many different approaches to teaching visual art. Nonetheless, some historical developments can be identified when looking at visual arts educational practices in New Zealand over the past 100 years.

\section{A Brief Historical Overview of Visual Arts Education}

\section{The First Kindergartens: A Teacher-Directed, Rote Art Curriculum}

The early childhood services that were dominant in New Zealand before World War 2 were kindergartens, which was a teacher-led service originally for children of the poor. Programs and teacher practice were based on ideas developed by German educationalist Fredrick Froebel. The approach to teaching was authoritarian and formalized. Teacher practice in the early kindergartens was very directive, and art activities strictly timetabled (Lawrence, 1952; May, 1997). Characteristics of a teacher-directed, rote art curriculum are evident in these early kindergartens, where the emphasis of art activities "involved dexterity and fine motor skills, neatness, memorization, and following directions" rather than individual creative self-expression (Bressler, 1994, p. 93). The New Zealand kindergarten movement remained wedded to traditional Froebelian ideas until after World War 2.

\section{Child-Centred Free Play and the Development of the Playcentre Movement}

Post-war influences from international developments in child psychology and education, for example, the progressive education movement based on the ideas of American educationalist and philosopher John Dewey, began to have an impact in New Zealand educational settings (Visser, 2005). Dewey's ideas called attention to the necessity of children's play being grounded in "the child's experiences of the real world" (May, 1997, p. 113) and learning by doing. Ideas such as these began to be embraced by the new playcentre movement (a parent-led, cooperative approach to early childhood education that started in 1941). The New Zealand kindergarten movement also embraced these ideas. An emerging "free-play" approach to learning was deemed to be the most suited to the education of young children.

Visual art learning experiences such as painting, collage, and clay were important activities that were provided in a free-play curriculum. The role of the parent or teacher was to let children play and create "freely and spontaneously" (Somerset, 1948, p. 14). It was important that adults did not interfere with the child's engagement in art "in order to preserve the developing character of the child" (Boughton, 1999, p. 4) and that they provided children with assistance only when they needed it. Playcentre also published literature for parents and teachers involved in young children's learning. Magic Places (Brownlee, 1983, 1991, 2004) became a significant visual art text for New Zealand early childhood educators and parents. This book has been, and remains, hugely influential in determining teacher practice in visual art in early childhood contexts in New Zealand. 


\section{The Developmentally Appropriate Curriculum}

At this time, early childhood teacher training, which was only available to kindergarten teachers until 1975, was influenced strongly by Piaget's theories of education. This orientation supported ideas generated from visual art research by American educators and researchers, such as Kellogg (1969) and Lowenfeld (1957), who believed there were distinct, universal developmental patterns in children's art (Koster, 1997). During the 1980s, early childhood education in New Zealand was also strongly influenced by the American developmentally appropriate practice (DAP) model of early childhood education. In this model, visual art was seen mainly as a vehicle for individual creative expression and the exploration of materials (Bredekamp, 1986).

A uniquely New Zealand visual art education initiative emerged during the 1980s. The Structured Environment Allowing for Communicative Original Happenings (known as SEACOH) was focused on the provision of child-centred visual art experiences (Terreni, 2010). Its aim was to liberate children from undesirable teacher-structured art activities by providing specialized furniture, such as attractive open shelving and screen printing tables, to give children free access to materials and the ability to make their own choices. This was seen as a way to assist children's increased self-determined engagement in art making (Lewis, 1998).

\section{An Emerging Sociocultural Orientation}

During the 1990s, new theories in visual art education, and education generally, emerged which began to question some of the assumptions and practices of developmental theory in visual art education (Kindler, 1996). Gardner's (2000) work and theories on multiple intelligences, whilst retaining some aspects of developmental theory with regard to visual art education, suggested that visual art was an important dimension to children's cognition and thinking processes rather than only for creative expression. Kindler and Darras (1994, as cited in Koster, 1997) suggested that visual art education involved a two-fold process: physical and cognitive development, as well as social and cultural learning. These ideas meshed well with sociocultural/constructivist theories of education from educationalists such as Bruner, Bronfenbrenner, and Vygotsky, whose ideas began to significantly influence early childhood pedagogy in New Zealand (May, 1997; Smith, Grima, Gaffney, \& Powell, 2000) and, in 1996, the development of Te Whāriki.

\section{The Project Approach and Reggio Emilia}

In the late 1990s, Reggio Emilia early childhood programs and the Project Approach (Katz \& Chard, 1989) were becoming known to early childhood educators in New Zealand. One experienced education commentator recently remarked:

In the early 1990s when their book [Engaging Children's Minds: The Project Approach] was published, it made a big impact on teachers and supported them to go beyond themes [for art activities].... The step by step approach that the formula of the Project Approach offered gave teachers a system that they felt comfortable to follow when starting something new. The Project Approach provided a helpful starting point to launch a new way of teaching. (C. Bayes, personal communication, June 29, 2014)

These two approaches highlighted the ways in which the arts provide abundant opportunities for children to use multiple symbolic languages, particularly visual art, to mediate their thinking and make their thinking visible (Brooks, 2005; Eales, 1996; Project Zero \& Reggio Children, 2001). From 2000, Reggio Emilia pedagogical approaches and ideas became increasingly popular with teachers in New Zealand. This popularity can, in part, be attributed to the development of Reggioaffiliated organizations (see, for instance, Reggio Emilia Inspirations and Reggio Emilia Association of New Zealand). Teachers were also starting to go on organized tours to Reggio Emilia, as well as to Australia, to visit successful ReggioEmilia-inspired programs operating there. 
Consequently, in the late 1990s and into the new century, a sociocultural/constructivist orientation in visual art education slowly began to challenge the developmentalist view that children's artistic growth is the result of "natural, genetically preprogrammed unfolding of dispositions controlled by maturation" (Kindler, 1996, p. 10). Rather than setting up wellresourced art areas and then standing back to let children engage without adult input, active teacher engagement with children in this domain was increasingly seen to provide opportunities for children to "talk about, critique and reflect upon their representation of their worlds" (Gunn, 2000, p. 160). This approach to visual art involved teacher practices such as scaffolding, discussion, modelling specific skills, and facilitating or "provoking" art learning experiences (Kindler, 1995; Visser, 2005).

\section{Current Approaches and Practices in Visual Art Education in New Zealand}

Despite this slow pedagogical shift, a number of researchers (Clark \& de Lautour, 2007; Gunn, 2000; Lewis, 1998; Pohio, 2009; Richards, 2009; Richards \& Terreni, 2013; Terreni, 2009; Visser, 2006) have noted that many New Zealand early childhood teachers today still retain a noninterventionist, hands-off stance in relation to visual art education. Nonetheless, there are also examples of teachers taking a very active role in fostering visual arts education and engaging actively in intentional teaching (Duncan, 2009) in this domain.

The development of the e-magazine ecARTnz (see http://www.elp.co.nz/ecartnz_e_magazine_on_arts_education.cfm) has given early childhood teachers in New Zealand a forum for showcasing exciting and innovative visual art projects, often driven by children's interests (emergent curriculum) but sometimes by teachers. A recent publication, Kia Tipu te Wairua Toi-Fostering the Creative Spirit: Arts in Early Childhood (Clark, Grey, \& Terreni, 2013) and an influential DVD, Visual Arts Inspirations: People, Places, and Things (Auckland University, 2012), have also been vehicles for encouraging new thinking and approaches to visual art education. These publications showcase examples of high-quality visual arts teaching and learning in New Zealand early childhood settings. The exemplars discussed in the following section are drawn from these sources and connect to the fundamental premise of Te Whāriki that young children learn most through their relationships with people, places, and things.

\section{Learning About People - All the Colours of the Earth: Painting Our Diversity}

Teachers at Papamoa Kindergarten in Tauranga work in an ethnically diverse community and are respectful of cultural and social differences (Wright, 2014). An investigation into ethnic diversity arose from a teacher's observations of a group of 4-year-old children who were playing in the family area with a selection of different ethnic dolls. After a few days of watching and listening, the teacher noticed that only the white European-looking dolls were being played with. She asked why and one of the children replied, "That's because he is a bit too brown for me. I like white."

Using a picture book, All the Colors of the Earth (Hamanaka, 1994), which describes people's skin colour in different ways, teachers used the children's comments and the picture book to provoke an exploration of skin colour through the painting of self-portraits. Children were encouraged to look closely at their own and each other's skin colour. Some children identified their skin colour as "white" or "brown," yet when they put brown and white paint on the back of their hands, they realized that these basic colours did not have enough variation to create a match for their skin tone.

Teachers also encouraged the children to look carefully at themselves by using mirrors, and helped the children to mix different paints to find the closest colour match for their skin. This was a lengthy process of investigation, but one which encouraged the children to think deeply about what they were doing. The colour mixing "enabled children to explore and 're-see' their skin colour. Through discussion, thoughtful deliberation and self-discovery, they moved from describing themselves and others as monotone pink, white, black or brown to using more sophisticated language to describe their skin tone" (Wright, 2014, p. 7). The teachers extended the children's ideas by getting them to think about what foods would best describe their skin colour and that of their friends. One of the children said, "My eyes and eyelashes look like the sun. My 
skin is like Caramello chocolate bar brown." A series of portraits were painted by the children using careful observations of themselves and their new knowledge about skin colour.

The project lasted for ten weeks and at its conclusion one of the teachers stated:

Describing themselves supported children's developing awareness of, and appreciation for, similarity and more importantly, for uniqueness and difference.... Supporting young children to recognise and acknowledge diversity and difference is a fundamental component of intercultural education. As Aotearoa [New Zealand] becomes more ethnically and racially diverse, teachers as agents of social justice have a fundamental role in supporting children's working theories about diversity and difference. (Wright, 2014, p. 8)

\section{Learning About Place_-There's a Taniwha (Monster) Down Our Drain}

Sobel (2004, as cited in Rosenthal, 2008) suggests that place-based education is "the process of using the local community and environment as a starting point to teach concepts in language, arts, mathematics, social studies, science, [art], and other subjects across the curriculum" (p. 7). By providing hands-on learning experiences, this approach to education can help children develop stronger ties to their community and increase their appreciation for their local environment.

The teachers at Paparangi Kindergarten in Wellington have a strong commitment to providing a bicultural curriculum, and place-based education is part of this. To encourage an exploration of place through the visual arts, one of the teachers used her skills in art and design to foster an investigation of the taniwha (a mythical Māori monster) that the children believe lives down a drain at the kindergarten.

According to kindergarten folklore, the taniwha has been living there for a long time. However, when the teacher asked more about it, no one seemed to know why it was living there or where it came from. This prompted her to think about how to extend and deepen understandings about the myth. She remarked:

The taniwha legend resonated with me. I saw the story as a way I could use my background in art and design to help the tamariki (children) deepen their connection to our place in the community, to Māori myths, as well as to their lived reality at the kindergarten. Moreover, my study (at Victoria University) illustrated to me that the environment around us could and should be used to enhance learning for the tamariki. So, reflecting on this, one morning I sculpted a large taniwha in the sandpit as a provocation for the children. (Wilson Jackson, 2013, p. 11)

The teacher observed that throughout the day, groups of children worked with the taniwha in the sandpit in very different ways. She saw children adding to her design, embellishing it with natural resources, making water come out of its mouth, and constructing a trench around its body to make a river. She felt that this learning opportunity had a big impact on the children because they revisited the ideas many times over the following weeks. It also resulted in a lot of collaborative play where ideas were shared and children worked together.

The creation of an illustrated book about the taniwha was another strategy the teacher used to extend the children's learning and engagement in visual art and storytelling. The book was a collaborative effort between the teachers and the children. Illustrations for the book were discussed with the children. Research, via Internet searches, produced ideas about taniwha as well as other aspects of the story. Relevant images were printed off and children drew their own pictures based on these images, using oil pastels on black paper.

As well as including children's drawings in the book, the teacher used Photoshop to incorporate a photograph of the children into one of their own illustrations. To do this, she encouraged the children to perform the story they had written. As they performed the story, she took photos of them for the book and, in the process, realized that performance of the story added 
another dimension to the children's own lived experience of their story. At the end of the book-making process, copies were made for the children to take home. The picture book continues to be read at the kindergarten to this day.

\section{Learning About Things-Spider Invasion}

Teachers at St. Andrews Epsom Early Childhood Centre in Auckland actively encourage visual art as a way of extending children's thinking and learning. The teachers have described their approach to art education as "hybrid—wandering between the two pointers of socio-constructivism and the Project Approach depending on what we're doing" (M. Johnston, personal communication, June 29, 2004). Teachers take a lead role in developing projects, actively scaffolding children's skills and ideas.

An exploration of spiders, which developed into an extensive learning project that lasted several months, began when a child shared her favourite book about spiders and some of the drawings she had done at home with her teachers. As a result, many other children declared their interest in spiders and consequently, with encouragement from the teachers, a study of spiders began.

The teachers' involvement in observational drawing, which is done alongside the children, is an important part of the centre's visual arts program. Picture books, models of spiders, images from the Internet, and real spiders were used for the observational drawing of spiders. The study also facilitated the learning of the technical names of a spider's body parts and about different spider habitats. When the drawings were completed, they were displayed prominently in the centre.

The drawings and the learning that had resulted from the observations were used to inform further spider creations by the children using different art mediums. For instance, a student teacher shared her own personal interest in jewellery making using wire and enamel with the children. Consequently, children began making spiders out of wire, developing new skills to create the three-dimensional forms. When the wire spiders were completed, they were hung in a tree outside and, much to the delight of the children and teachers, a real spider that lived in the tree spun a web around them.

Over many weeks, the children and teachers carefully noticed and observed spider behaviour in the centre. Clay, painting, and silkscreen printing were all used to further children's visual art learning experiences, but the interest in spiders also extended into other areas of the curriculum: music, science, language, and literacy. The project culminated in an exhibition of the children's multimedia work. One of the teachers involved in the exhibition remarked:

The exhibition pulled together the various aspects of spiders we had discovered ... the wide variety of habitats and the many characteristics of each and every spider [studied]. It was a successful evening, and the exhibition gave each child a sense of belonging to our centre's community and helped foster their selfesteem by seeing their gorgeous art work being highly valued by all the visitors. (M. Johnston, personal communication, July 2010)

\section{Conclusion}

The three examples described in this article highlight the ways in which visual arts education can connect with significant learning opportunities for young children. Art can be a vehicle for supporting young children's increased knowledge and understanding in important areas, such as social justice, awareness of significant features of their local environment, and the study of natural phenomena. In all of these projects, the teachers' and/or the children's interests were used to start the projects and to drive them to their conclusion. The provision of unlimited time, quality resources, and intentional and often imaginative teaching strategies enabled sustained opportunities for in-depth learning to occur. One of the aspirations of Te Whāriki is that children in early childhood services in New Zealand "grow up as competent and confident learners and communicators, healthy in mind, body, and spirit, secure in their sense of belonging and in the knowledge that they make 
a valued contribution to society" (New Zealand Ministry of Education, 1996, p. 9). The visual arts, as these examples illustrate, provide many opportunities for children to become competent and confident learners.

However, early childhood teachers in New Zealand need robust professional development opportunities to be able to successfully critique their practice in this domain. This is increasingly important when there are new curriculum developments, educational policy changes, and pedagogical shifts (not only in the early childhood sector but also in the other education sectors). Awareness of new ideas, research, and innovative teaching practices are also necessary so that vibrant, quality arts education learning experiences are provided in early childhood settings. If these opportunities are made available to teachers, I believe the future for visual arts education in early childhood settings in New Zealand will be a healthy one.

\section{References}

Auckland University. (2012). Visual arts inspirations: People, places, and things. Auckland, New Zealand: Author.

Boughton, D. (1999). Visual arts education. In M. Ben-Peretz, S. Brown, \& R. Moon (Eds.), International encyclopedic dictionary of education (pp. 1-9). London, England: Routledge.

Bredekamp, S. (1986). Developmentally appropriate practice in early childhood programmes serving children birth through age 8. Washington, DC: National Association for the Education of Young Children.

Bressler, L. (1994). Imitative, complementary, and expansive: Three roles of visual arts curricula. Studies in Art Education, $35(2), 90-104$.

Brooks, M. (2005). Drawing as a unique mental development tool for young children: Interpersonal and intra personal dialogues. Contemporary Issues in Early Childhood, 6(1), 80-91.

Brownlee, P. (1983/1991/2004). Magic places: A guide for adults to encourage young children's art work. Auckland, New Zealand: Playcentre Federation.

Clark, B., \& de Lautour, N. (2007). Art in the early childhood curriculum. Hands on or hands off: Are these approaches polarised or is there a place for shared journeys? Paper presented at the Early Childhood Convention, Rotorua, New Zealand.

Clark, B., Grey, A., \& Terreni, L. (Eds.). (2013). Kia tipu te wairua toi-Fostering the creative spirit: Arts in early childhood education. Auckland, New Zealand: Pearson.

Duncan, J. (2009). Key question: How do you make your daily decisions for teaching and learning in your ECE setting? Retrieved from: http://www.educate.ece.govt.nz/learning/exploringPractice/InfantsandToddlers/EffectivePractices/ IntentionalTeaching.aspx

Eales, R. (1996). A Vygotskian approach to teaching art in the early childhood curriculum. Dunedin, New Zealand: Dunedin Kindergarten Association.

Gardner, H. (2000). The disciplined mind: Beyond facts and standardized tests, the K-12 education. New York, NY: Penguin Putnam.

Gunn, A. C. (2000). Teachers' beliefs in relation to visual art education in early childhood centres. New Zealand Research in Early Childhood Education, 3, 153-163. 
Haggerty, M. (2003). Reconceptualising notions of curriculum: The case of Te Whaariki. New Zealand Research in Early Childhood Education, 6, 35-49.

Hamanaka, S. (1994). All the colors of the earth. New York, NY: Harper Trophy.

Katz, L. G., \& Chard, S. C. (1989). Engaging children's minds: The project approach. Norwood, NJ: Ablex.

Kellogg, R. (1969). Analyzing children's art. Mountain View, CA: Mayfield.

Kindler, A. M. (1996). Myths, habits, research, and policy: The four pillars of early childhood art. Arts Education Policy Review, 4, 24-30.

Koster, J. B. (1997). Growing artists: Teaching art to young children. New York, NY: Delmar.

Lawrence, E. (1952). Friedrich Froebel and English education. London, England: University of London Press.

Lewis, T. (1998). Early childhood art education: A dilemma for students and teacher educators. Journal of Educational Research, 4(1), 61-68.

Lowenfeld, V. (1957). Creative and mental growth. New York, NY: Macmillan

May, H. (1997). The discovery of early childhood: The development of services for the care and education of very young children, mid eighteenth century Europe to mid twentieth century New Zealand. Auckland, New Zealand: Auckland University Press.

May, H. (2002). Aotearoa-New Zealand: An overview of history, policy, and curriculum. Magill Journal of Education, 37, $19-36$.

New Zealand Ministry of Education. (1996). Te Whāriki. He whāriki mātauranga mō ngā mokopuna o Aotearoa: Early childhood curriculum. Wellington, New Zealand: Learning Media.

New Zealand Ministry of Education. (2014). What are the arts about? Retrieved from: http://nzcurriculum.tki.org.nz/TheNew-Zealand-Curriculum/Learning-areas/The-arts

Nuttall, J. (2003). Introduction: Weaving Te Whāriki. In J. Nuttall (Ed.), Weaving Te Whaariki: Aotearoa New Zealand's early childhood curriculum document in theory and in practice. Wellington, New Zealand: New Zealand Council for Educational Research.

Pohio, L. (2009). Reggio Emilia pedagogy in early childhood education: How can this approach enhance visual arts experiences in New Zealand? He Kupu, 2(2), 10-18.

Project Zero \& Reggio Children. (2001). Making learning visible: Children as individual and group learners. Reggio Emilia, Italy: Reggio Children.

Richards, R. (2009). Jake just does scribbles but I do pictures: Drawing self-efficacy and the messages four-to nine-yearold children give and receive about their drawing. Saarbrücken, Germany: Lambert Academic.

Richards, R., \& Terreni, L. (2013). Actively engaging through the visual arts: Recognising children's artistic experiences and repertoires. In B. Clark, A. Grey, \& L. Terreni (Eds.), Kia tipu te wairua toi-Fostering the creative spirit: Arts in early childhood education (pp. 39-51). Auckland, New Zealand: Pearson. 
Ritchie, J. (2003). Te Whāriki as a potential lever for bicultural development. In J. Nuttall (Ed.), Weaving Te Whaariki: Aotearoa New Zealand's early childhood curriculum document in theory and in practice (pp. 79-109). Wellington, New Zealand: New Zealand Council for Educational Research.

Rosenthal, J. (2008). Place based education research and studies annotated bibliography. Retrieved from: http://www. promiseofplace.org/assets/files/research/Rosenthal2008PBEAnnotatedBibliography.pdf

Smith, A., Grima, G., Gaffney, M., \& Powell, K. (2000). Early childhood education literature review: Report to the Ministry of Education. Otago, New Zealand: Children's Issues Centre.

Somerset, G. (1948). I play and I grow. Auckland, New Zealand: New Zealand Playcentre Federation.

Te One, S. (2003). The context for Te Whaariki: Contemporary issues of influence. In J. Nuttall (Ed.), Weaving Te Whaariki: Aotearoa New Zealand's early childhood curriculum document in theory and in practice. Wellington, New Zealand: New Zealand Council for Educational Research.

Terreni, L. (2008). Providing visual arts education in early childhood settings that is responsive to cultural diversity. Australian Art Education, 31(1), 66-79.

Terreni, L. (2009). Aligning early childhood visual art education with socio-cultural theory and practice: A personal pedagogical stance on the relationship between theory and visual arts education practice in New Zealand early childhood education. Journal of Australian Research in Early Childhood, 16(1), 63-72.

Terreni, L. (2010). A history of visual art education in early childhood in New Zealand: Looking backwards to go forwards. International Art in Early Childhood Research Journal, 2, 1-11.

Visser, J. (2005). The historical, philosophical, and theoretical influences on early childhood visual arts education in Aotearoa New Zealand. ACE Papers, 16, 25-38. Retrieved from: http:/www.education.auckland.ac.nz/uoa/fms/ default/education/docs/word/research/foed_paper/issue16/ACE_Paper_2_Issue_16.doc

Visser, J. (2006). Teachers'beliefs and practices in toddler art education: A tension between developmental and sociocultural perspectives (Master's thesis, University of Auckland, New Zealand).

Wilson Jackson, P. (2013). There's a taniwha down our drain: Strengthening connections to place through art and design. ecARTnz, 8. Retrieved from: http://www.elp.co.nz/files/ecartnz_issue_8.pdf

Wright, G. (2014). All the colours of the earth: Painting our diversity. ecARTnz, 9. Retrieved from: http://www.reanz.org/ files/2813/9866/3440/ecARTnz_Issue_9_2014.pdf 